\title{
12
}

\section{Holocene lowland vegetation change and human ecology in Manus Province, Papua New Guinea}

\author{
Matthew Prebble \\ Department of Archaeology and Natural History, College of Asia and the Pacific, Australian National \\ University, Canberra, Australia \\ matthew.prebble@anu.edu.au

\section{Jean Kennedy} \\ Department of Archaeology and Natural History, College of Asia and the Pacific, Australian National \\ University, Canberra, Australia
}

\section{Wendy Southern}

First Assistant Secretary, Department of the Prime Minister and Cabinet, Canberra, Australia

\section{Introduction}

This paper concerns evidence for past human impacts on the environment in the lowland tropical New Guinea region. Against a background regional overview, we consider two sequences, one archaeological, the other palaeoecological, from opposite ends of Manus Island, the largest island of the Admiralty Islands that now constitute Manus Province, Papua New Guinea. Contrasts in these local sequences prevent their easy alignment with grand narratives of regional prehistory. We show instead that closer examination of local contexts, especially the nature of agroecosystems, gives useful insights that help to disentangle natural processes of forest vegetation change and the effects of human activities. We consider aspects of the ecology of the tree genus Calophyllum L. (Clusiaceae), which occurs in both sequences, to assess the possibility of a human role in the dynamics of forest dominated by Calophyllum euryphyllum Lauterb. (Clusiaceae). 


\section{People and environment in the New Guinea region: An overview}

\section{Palaeoecological context}

In the New Guinea region, the late-Quaternary environment since humans arrived 40,00060,000 years ago was affected by altitudinal fluctuations of vegetation zonation in the highlands and sea-level changes around the coasts, both linked to the glacial cycle, with significant changes around the Last Glacial Maximum and less dramatic adjustments consequent on the high-sea-level stand in the mid Holocene.

Ecological mechanisms for vegetation change on tropical islands include competing species interactions, abrupt natural events (such as volcanic ash falls, tsunamis or cyclones), climate change, changing terrestrial insularity associated with geological activity and eustatic or isostatic sea-level fluctuations, and human interference. Palaeoecological data, particularly spanning the Holocene, have established partial chronological frameworks for these processes by recording ecological trends in different local contexts. Fine-scale vegetation changes can be measured from subfossil proxies (e.g. microfossil and macrobotanical analyses) and then used to infer conditions under which certain plant taxa have responded to disturbance. Similarly, palaeoclimatic patterns can be inferred from a number of subfossil, chemical and sedimentary proxies from the same archives. Surprisingly little evidence of this kind has been identified from the northern New Guinea lowlands and adjacent islands. Here we summarise the palaeoecological context for past vegetation changes in the region.

\section{The Pleistocene}

In New Guinea, investigating the role of humans in vegetation change is complicated by the lack of palaeoecological records that show changes before and after human colonisation, about 40,000-60,000 yr BP. Palynological records from mainland New Guinea that adequately represent these shifts have been reviewed recently by Hope $(2007,2009)$. The sites are mostly in basins in the high-elevation New Guinea ranges (Haberle 1998; Hope 2009). Archaeological evidence suggests people must have been in these areas since around 40,000 yr BP but sustained impacts on forest vegetation did not occur until around 30,000 yr BP at Kosipe and around 21,000 yr BP at Haeapugua.

Despite the growing evidence of Pleistocene occupation of the lowlands and coasts of New Guinea and its offshore islands (Allen 2003; O'Connor and Chappell 2003; O'Connell and Allen 2004), little palaeoecological evidence is available. Hope and Tulip (1994) summarised the main complicating factors that make the lowland tropics a challenge for palaeoecologists. Because rapid organic accumulation rates of between $10 \mathrm{~cm}$ and $80 \mathrm{~cm}$ in 100 years are not uncommon for both lakes and swamps, sections of peat or organic muds rarely exceed Holocene ages (Walker and Chen 1987; Hope and Tulip 1994; Osborne et al. 1996). Hope and Tulip (1994) point out that this problem is compounded by the low deposition rate of pollen in the humid tropics (after Kershaw and Hyland 1975). High local floristic diversity with a bias towards entomophilous and low pollen-producing taxa is a characteristic of the lowland tropical floras. Even when pollen preservation is high and deposition is continuous, many New Guinea palaeoecological records show marked transitions in forest vegetation during the Pleistocene but reveal no indication of ecological forcing factors, disturbance or anything else.

The pollen record from Hordorli, a swamp basin at $780 \mathrm{~m}$ altitude in the Cyclops Mountains near Lake Sentani, West Papua/Irian Jaya, Indonesia (Figure 1), is unique in that it provides a 50,000-year record of lowland vegetation change (Hope and Tulip 1994; Hope 1996). The suite of palaeoecological evidence that should mark initial human colonisation, 



\section{Inset B}

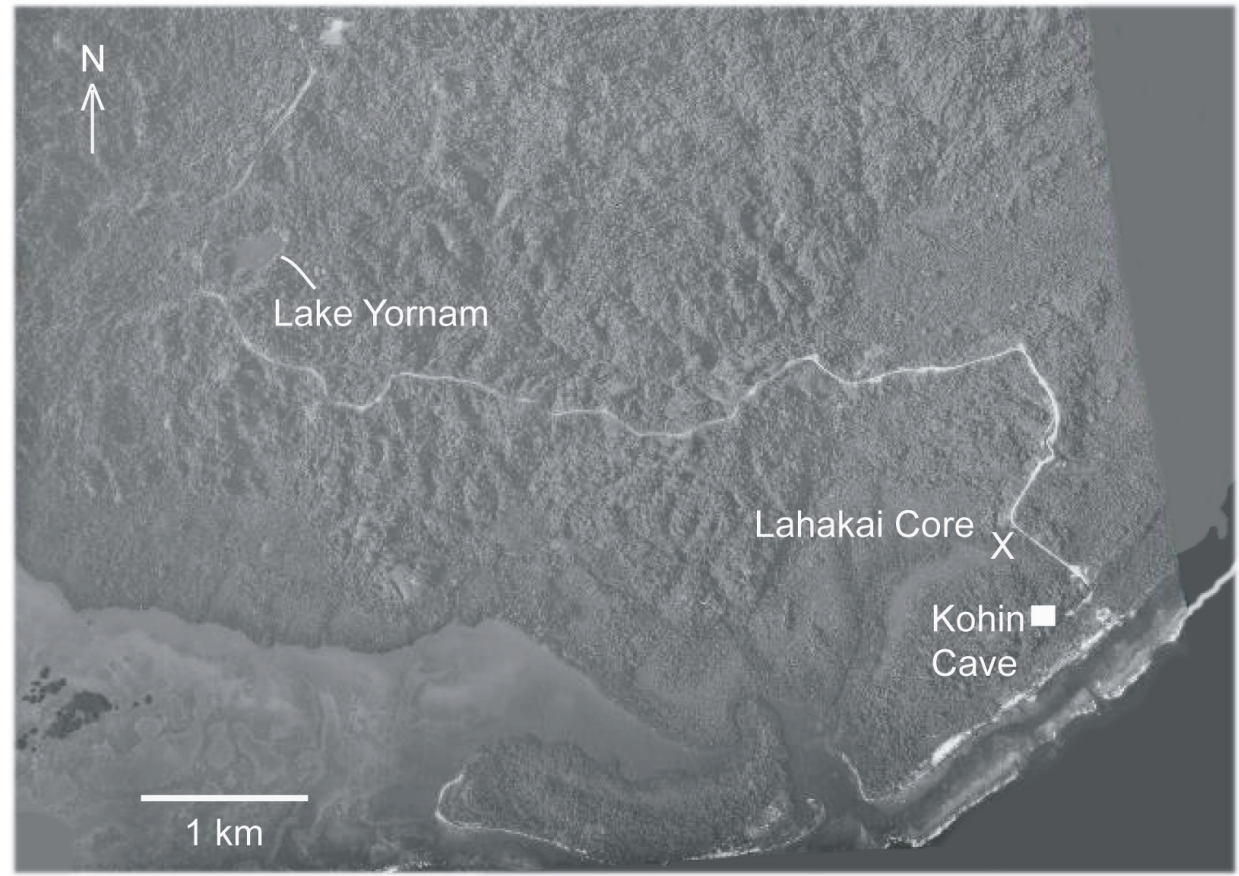

Figure 1. Map of Papua New Guinea, showing sites, the location of Manus Province and Lahakai Swamp in southeast Manus 
such as increased fire frequency and increases in the abundance of secondary vegetation, is not conclusively represented at Hordorli until the Holocene. The Hordorli record also shows that closed tropical and lower montane forests have continuously occupied many areas despite human occupation. Hope and Haberle (2005) suggest that the lack of fire signals recorded at sites such as Hordorli may represent delayed intensive occupation of wetter sites.

There are no palaeoecological archives that span the Pleistocene from the tropical New Guinea islands. Given that the flora of these islands represents a subset of the mainland, there is no reason to presume that past vegetation change would be very different. Hope and Haberle (2005) suggest that the coastal lowland catchments of the Popondetta, Markham, upper Ramu and Sepik areas may have been drier during the Pleistocene than at present, dominated by Nauclea woodlands and possibly subject to natural fires, further complicating any palaeoecological signature of human presence. Such a model of vegetation change may also apply to the New Guinea islands.

\section{The Holocene}

Human influence on New Guinea vegetation change becomes more apparent in palaeoecological records of the Holocene, and can be correlated with archaeobotanical evidence for the beginning of plant domestication and agriculture (Yen 1996; Denham et al. 2004; Fairbairn 2005; Haberle 2007). Again, records are concentrated in the highlands of Papua New Guinea. Haberle and David (2004) have argued that increases in charcoal particles and Casuarina pollen, a secondary forest indicator, represented in a number of New Guinea highland palaeoecological records may signal the expansion of active and fallow cultivation areas during the mid Holocene.

In the coastal tropics of New Guinea, little palaeoecological research has concentrated on resolving questions of subsistence practice. Most pollen records have been retrieved in an effort to map the extent of mangrove sediments and the response of vegetation to coastal progradation and sea-level change. Mangrove sediments have been found hundreds of kilometres upriver in the Ramu and Sepik (Swadling and Hope 1992; Chappell 2005), indicating that a large estuary existed in the early mid Holocene before coastal progradation formed the present backswamp complex. Rapid siltation and coastal progradation has been demonstrated from mangrove sediments and geomorphological features found along the southern coast of New Guinea (Ellison 2005) and along the Fly-Digul platform, suggesting that the available land area for human occupation was limited during the early Holocene (Chappell 2005).

The pollen record from Lake Wanum, a lowland tropical lake in the Markham Valley, northern Morobe Province, Papua New Guinea (Figure 1) (Garrett-Jones 1979), provides the most continuous Holocene record so far of lowland vegetation change for mainland New Guinea. The lake has a rapid accumulation rate of organic-rich sediment during the Holocene. The record shows that an open sedge swamp surrounded by riparian forest/woodland persisted throughout the Holocene with an increase in dry-land grassland, secondary forest (including Nauclea and Macaranga) and burning after about 5500 yr BP.

In the Hordorli pollen record, charcoal particles first appear after 10,900 yr BP, and probably indicate a minor level of human activity. An increase in secondary forest species after 7000 yr BP may be a result of minimal human activity or, as Hope and Tulip (1994) suggest, may be the result of warmer conditions and shorter tree life in the lower montane forests.

The Wanum and Hordorli records both fail to provide any direct palaeoecological evidence for the initiation of root/tuber cultivation complexes and tree crops. Garrett-Jones (1979:295, 329) identified taro (Colocasia esculenta) pollen in the basal pollen zone of a $20 \mathrm{~m}$ deep core (core LWII), dated to around $9000 \mathrm{yr}$ BP (identification confirmed by Haberle 1995). This represents the earliest subfossil record of $C$. esculenta from New Guinea, but the vegetation represented by the sample containing it appears to be a sedge swampland with riparian forest 
and grasslands present on the dryland slopes. Prebble et al. (In prep.) consider the early Holocene C. esculenta to represent most likely a wild form present as part of the natural distribution in marginal swampy habitats, or less likely, a feral population escaped from earlier human introductions.

\section{Human prehistory of the northern New Guinea lowlands and adjacent islands}

People reached New Britain and New Ireland around 35,000 yr BP, and Manus more than $20,000 \mathrm{yr}$ BP. Although lowered Pleistocene sea levels never brought the islands of the Bismarck Archipelago significantly closer to each other or to the main Sahul landmass, New Britain and New Ireland could be reached by crossing between intervisible islands, distances shorter than those already accomplished through Wallacea. Manus, in contrast, has always been a very small target, far below the horizon from any direction.

Excavated sites are too few and scattered to provide a clear picture of the earliest human phase in the Bismarck region. The New Ireland Pleistocene sites suggest small groups, mobility, foraging for resources of land and sea, and a mixed diet (Gosden 1993, 1995; Allen 2000, 2003; Specht 2005).

In Manus, the basal occupation of the Pamwak rock shelter may be significantly older than the oldest ${ }^{14} \mathrm{C}$ date of 21,000 yr BP. Carbonised Canarium nut shell and faunal remains dating to the terminal Pleistocene have been interpreted to represent human introductions from mainland New Guinea (Fredericksen et al. 1993). Undated, but probably also of Pleistocene age, are flaked stone tools salvaged from southwest Manus open sites destroyed by logging (Kennedy et al. 1991; Kennedy 1992, 1997, 2002; Ambrose 2002a).

By the end of the Pleistocene, an emergent pattern of movement of resources across the Bismarcks suggests that people had begun modifying their environments and making use of inter-island connections to supplement locally available resources. Obsidian and animal translocations suggest people made interisland crossings between mainland New Guinea, New Britain, New Ireland and Manus (Flannery and White 1991; Gosden 1992; Allen and Gosden 1996; Heinsohn 2003; Specht 2005).

Archaeological sites of the early to middle Holocene in the Bismarcks have yielded material from wider catchments than before, and in larger quantities. There is a greater range of artefacts and manufacturing techniques, including grinding of both shell and stone axes (Spriggs 1997; Allen 2000; Specht 2005). Food remains at several sites where conditions favoured preservation include fruit, nuts and other useful trees, most of them familiar in gardens today.

Although the record for Manus in the early to middle Holocene is very thin, the general pattern of resource use is consistent with the rest of the Bismarcks. Whether tree crops were important in early to middle Holocene Manus is unknown, but it seems likely they were, given their earlier presence and prominence elsewhere in sites in the Bismarcks (Gosden 1995; Specht 2005).

From about 3500 years ago, sites of the Lapita cultural complex extend from the Bismarck Archipelago east to Tonga and Samoa. The nature of these sites and their relationship to earlier sites in the southwest Pacific region and further west has been the subject of extended debate (Spriggs 1997; Terrell and Welsch 1997; Kirch 2000; Green 2003; Terrell 2004). The standard interpretation sees Lapita sites as the settlements of immigrant agricultural people, who spread relatively rapidly from Southeast Asia through the Bismarck archipelago and further east, and whose descendants include the Polynesians. In extreme forms of this view, these new settlers have been distinguished from earlier-established inhabitants of the southwest Pacific by sharply defined cultural and technological contrasts, including in particular the introduction of agriculture. Current debate reflects more subtle positions about the relative contributions of 
putatively Southeast Asian and Melanesian subsistence practices and technological traditions (Green 2003; Golson 2005; Lilley 2006).

Manus does not fit neatly into a regional synthesis of intercommunicating Lapita peoples, for unequivocally Lapita material from Manus consists of only eight sherds from three sites, none of them in the beach locations typical of Lapita sites elsewhere. Thus, what part Manus played in the Lapita phenomenon is problematic (Kennedy 1981, 1982, 2002; Allen 1991; McEldowney and Ballard 1991), although obsidian from Lou Island occurs in Lapita sites throughout the Bismarks, and beyond. The Lapita-phase archaeological data from Manus are too tenuous to support arguments for local transformation of the patterns of settlement or subsistence (Kennedy 1983, 2002).

The end of the Lapita phase in the Bismarcks, North Solomons, Vanuatu and New Caledonia region has been characterised as a shift away from the regional interaction implied by the relative homogeneity of the Lapita cultural complex (Spriggs 1997; Bedford and Clark 2001, 2003), resulting in the present-day cultural diversity for which Melanesia is noted.

Again, the small number of excavated sites is inadequate to outline the post-Lapita period of Manus. Although the quantity and diversity of material and numbers of sites are greater than in preceding periods, much is from contexts which do not allow reliable dating. In general, the material suggests widening connections, throughout Manus and beyond.

\section{The big picture: Changing subsistence and settlement patterns}

Because people have been in the New Guinea islands region since the late Pleistocene, it is reasonable to expect that archaeological and palaeoecological sequences should register the shift from mobile foraging to more settled life based on agroecosystems. But because of the variability and flexibility of current subsistence practices, it is less clear what sort of changes might be expected. Despite the strongly asserted association of the shift to agroecosystems with the Lapita horizon, direct archaeobotanical or palaeoecological evidence is lacking, and change is inferred from proxies, such as the presence of pottery, shifts in settlement location, density and size, and linguistic reconstructions of plant and garden-related lexicons. Although this inferred subsistence change at present dominates the grand narrative of regional prehistory, the nature of emergent Holocene subsistence is open to question.

There is growing biogeographic and genetic evidence that important components of southwest Pacific agroecosystems are indigenous domesticates (e.g. bananas, breadfruit, Pandanus and sago; Yen 1991, 1996; Kennedy and Clarke 2004). The importance of the tree crops that form an integral part of the regional subsistence pattern, extending back at least to the middle Holocene, and probably to the late Pleistocene (Fairbairn 2005), has been underestimated. The significance of tree crops in mid-Holocene, pre-Lapita times is part of continuing debate about the Lapita cultural complex (Gosden 1992, 1995; Yen 1996; Kennedy and Clarke 2004).

The tree-crop-based systems of the present day, unlike the wide-ranging foraging of the earlier Pleistocene sites, involve significant alteration of natural forests, although this does not necessarily entail major disturbance. They show considerable regional variation in crop mixes and cultivation practices, and allow very rapid change in response to localised exigencies. As a result, local sequences may be quite disparate, and involve subtle changes difficult to detect in palaeoecological data. 


\section{Manus Island: Local cultural and environmental sequences}

As sketched above, the archaeological record of Manus is meagre. Table 1 shows the excavated sites for which there is a reasonable assessment of radiocarbon ages or distinctive typology. There is a chronological bias towards the late Holocene, and a geographical one towards Lou Island and the eastern end of Manus. This largely reflects interest in the obsidian sources on Lou Island, shared by archaeologists and local sponsors of field work, as well as prehistoric inhabitants of the area. Historical records of European contact with Manus Province show a similar geographical bias (Kennedy et al. 1991).

Table 1. Archaeological sites of central/eastern Manus Province

\begin{tabular}{|l|c|c|c|c|l|}
\hline Site & Pleistocene & Early-mid Holocene & \multicolumn{2}{|c|}{ Late Holocene } & References \\
\hline & & & Lapita & Post-Lapita & \\
\hline Pamwak $^{\mathrm{a}}$ & $\mathrm{X}$ & $\mathrm{X}$ & & $\mathrm{X}$ & $\begin{array}{c}\text { Fredericksen et al. 1993, Spriggs } \\
\text { 1997, Ambrose 2002a }\end{array}$ \\
\hline Peli Louson $^{\mathrm{a}}$ & & $\mathrm{X}$ & & $\mathrm{X}$ & Kennedy 1983 \\
\hline Father's Water $^{\mathrm{a}}$ & & $\mathrm{X}$ & & $\mathrm{X}$ & Kennedy 1983 \\
\hline Kohin $^{\mathrm{a}}$ & & & $\mathrm{X}$ & $\mathrm{X}$ & Kennedy 1981 \\
\hline Mouk $^{\mathrm{b}}$ & & & $\mathrm{X}$ & $\mathrm{X}$ & McEldowney and Ballard 1991 \\
\hline Sasi (Baun) & & & & $\mathrm{X}$ & Ambrose 1988, 1991, 2002a \\
\hline Emsin $^{\mathrm{c}}$ & & & & $\mathrm{X}$ & Ambrose 1991, 2002a \\
\hline Pisik $^{\mathrm{c}}$ & & & & $\mathrm{X}$ & Ambrose 1991, 2002b \\
\hline Umleang $^{\mathrm{c}}$ & & & & & $\begin{array}{l}\text { Fullagar and Torrence 1991, } \\
\text { Ambrose 2002a }\end{array}$ \\
\hline
\end{tabular}

a. Manus Island, b. near Baluan, c. Lou Island

The eastern half of Manus Island has villages and hamlets scattered throughout the interior, as well as along the coasts, with associated gardens and tree crops including planted sago stands. Tree crops are very important in village environs, and scattered throughout gardens and fallow. Garden clearance usually does not involve burning. The island's western half, in contrast, has neither settlements nor garden areas in the interior. The relatively few villages are coastal, and depend largely on sago (Hide et al. 1996). The contrast implies different local histories of settlement and subsistence, and requires a much finer focus of inquiry than the regional big picture.

\section{Southwest Manus archaeological sequence}

In southwest Manus, despite the absence of recent interior settlement, salvage archaeology during logging recorded more than 100 settlement sites. These are concentrated on high ground, especially ridge crests and their intersections, and marked by large quantities of pot sherds and worked obsidian (Kennedy et al. 1991; Wadra 1991; Kennedy 1992, 1997). The number and scale of these sites, exposed, recorded and then obliterated within a relatively short period, provide information difficult to integrate with that from the controlled conditions and close-up view of archaeological excavation, providing very detailed information about a tiny sample of the past. While archaeologists dissect a small part of a site, relatively modest logging and other industrial operations can simultaneously expose and destroy whole archaeological landscapes. 
Despite destruction of the stratigraphic integrity of the southwest Manus sites, a few chronological and other inferences can be made from the salvaged artefacts. First, most of the sites are older than the forest, which can be no more than a few hundred years old: they are under, not in it. There is very little artefactual evidence referrable to the last few hundred years. Much of the distinctive pottery is not matched elsewhere in Manus or beyond. Since Lapitastyle sherds are lacking, on conventional grounds the entire corpus may be characterised as post-Lapita, though quite what that means in Manus is unclear.

At least 25 sites contain distinctive, elaborately retouched obsidian points, technologically identical to those from a Lou Island site dated about 1720 yr BP (Kennedy 1997; Ambrose 2002a). Whether the southwest points are of imported obsidian is not clear, since there is a local southwest Manus obsidian source associated with Mount Hahie (Figure 1). But quite apart from intriguing questions of the geopolitics of resource acquisition and technological skills that these artefacts raise (Kennedy 1997), they imply a horizon during which settlement density was at least as high as the present-day pattern of eastern Manus. And this, in turn, suggests a similar subsistence base, with taro gardens and extensive tree crops.

At a few southwest sites, distinctive large retouched flakes similar to artefacts dated at Pamwak to the late Pleistocene/early Holocene suggest earlier occupation.

The archaeological evidence from under the forest of southwest Manus thus suggests people have been present there since the Pleistocene. At some point, they began to make and/ or use pottery. About 1700 years ago, relatively intensive agriculture can be inferred. There is no direct evidence of what was grown, or when this phase ended. However, the lack of recent artefact types suggests that population decline and shift from inland to coastal settlement had occurred well before the period of European contact. Both the location and density of past settlements contrast with the present-day pattern. Since the growth of a forest dominated by Calophyllum spp. constitutes the most recent phase of the local sequence, understanding the dynamics of the forest is a necessary part of interpreting the human history of the southwest.

Logging in southwest Manus, begun in 1988, was prompted by the existence of a timber resource in a largely unpopulated area (Freyne and Bell 1982). In keeping with the aims of national forestry policy at the time, the Manus Provincial Government hoped the southwest Manus logging project would reduce the imbalance between the eastern and western halves of the island, bringing urban development and new technology to the west by construction of a township and veneer mill. Neither has eventuated. Appearances to the contrary, many of the trees are too old to yield useful timber, much less the peelable logs anticipated, and the project has been beset by long-running disputes (O'Collins and Lamothe 1989; Kennedy 1991; Ghai and Regan 1992:328; Anon. 2004). Logging proceeded despite recognition that the southwestern Manus Calophyllum-dominated forest is ecologically unusual, and that its dynamics are obscure (Kerenga and Croft 1984/85; Stevens 1995:63). While the archaeological record does not directly elucidate these dynamics, some relationship with preceding human activity is implied. Nevertheless, prominent NGO commentary on the timber resource insists it was in pristine condition before logging began (e.g. World Wildlife Fund 2001; Seacology 2008; National Geographic 2009). This is a familiar theme in critiques of forest resource use throughout the tropics (e.g. Bayliss-Smith et al. 2003; Willis et al. 2004).

\section{Southeast Manus palaeoecological sequence: Lahakai Swamp}

A preliminary palaeoecological investigation of Lahakai Swamp in southeastern Manus was undertaken with the aim of documenting Holocene vegetation change, in particular evaluating human impact and other disturbances on Manus (Southern 1987). After a broad survey of sites, Lahakai Swamp was chosen for its proximity to recent gardening and sago processing, 
and to Kohin Cave, an excavated archaeological site occupied intermittently from $3400 \mathrm{yr}$ BP to the present (Kennedy 1981). It is worth noting that nearby Lake Yornam (Figure 1), formed probably within a karst sinkhole deposit, revealed alkaline conditions unsuitable for the preservation of pollen (Southern 1987).

A series of raised Plio-Pleistocene fringing reefs, now forming karst cliffs along part of the southeast coast of Manus, have blocked the drainage of many south-facing valleys. Diverted creeks are visible behind the cliffs (see Figure 1) and swamp deposits have accumulated large amounts of organic material suitable for palaeoecological analyses. In 1987, when the site was cored, this swamp was maintained as a sago plantation and was intensively exploited by local landowners. The vegetation was dominated by a spineless form of sago palm (Metroxylon sagu) which formed nearly monotypic stands with few other plant taxa present (Figure 2 ). The surrounding hill slopes behind the swamp were heavily gardened. Some areas were recently cleared for new gardens, and adjacent areas remained in fallow secondary forest regrowth that included many exploited fruit and nut trees.

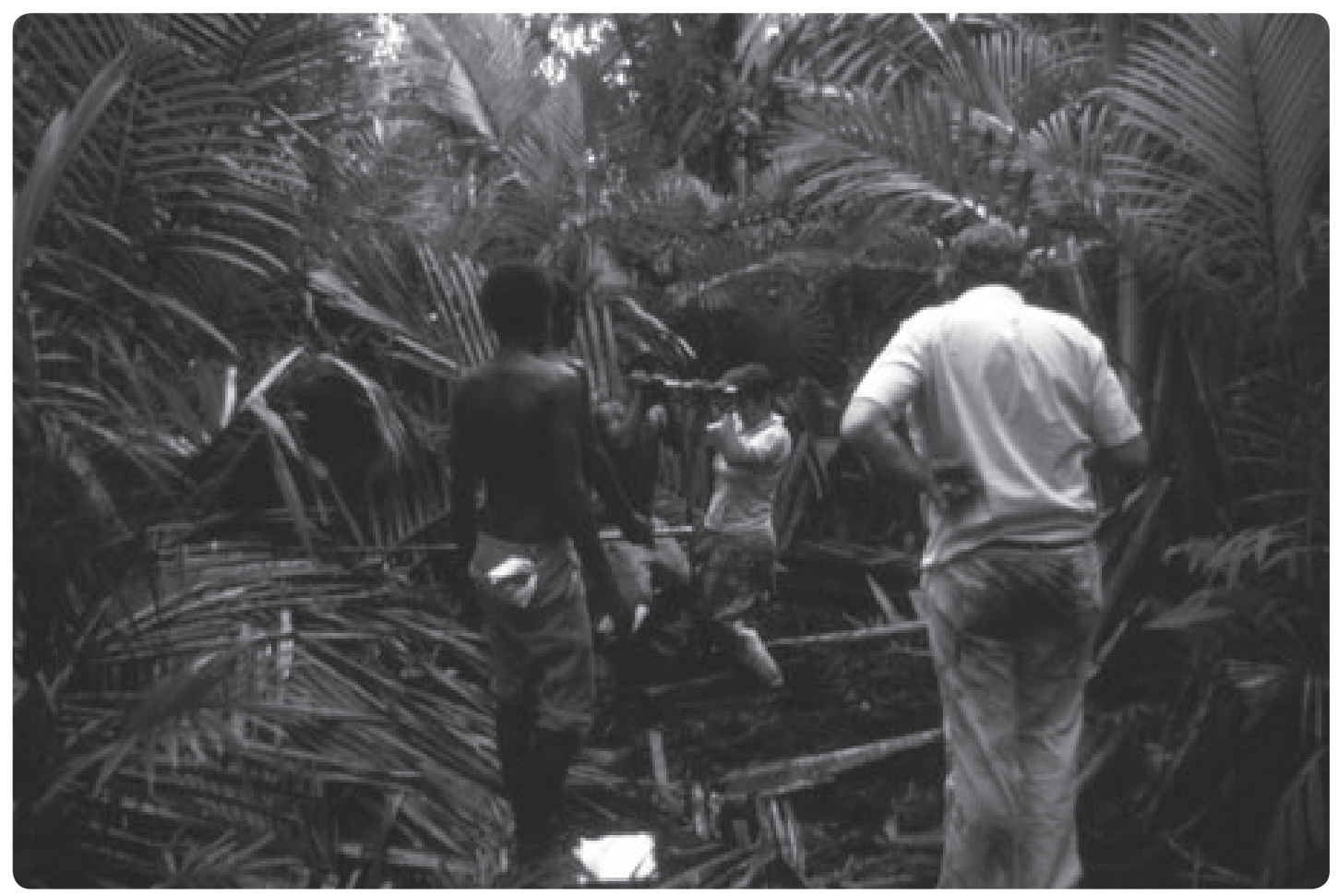

Figure 2. Coring the Lahakai Swamp site. Jack Golson watching Wendy Southern and local assistants. Photograph by W. Ambrose, 1987

\section{Methods}

Lahakai Swamp was cored using a Russian D-Section corer, collected in $40 \mathrm{~cm}$ length sections to a depth of $9.6 \mathrm{~m}$, at which point basal estuarine/marine-shell debris was encountered. The core was sampled at $10 \mathrm{~cm}$ intervals down to $630 \mathrm{~cm}$ and processed for palynomorphs using standard procedures (10\% HCL, hot $10 \% \mathrm{KOH}, 40 \% \mathrm{HF}$ and acetolysis for all samples) as described by Faegri and Iversen (1975). Samples were then washed in alcohol followed by tertiary butyl alcohol to dehydrate them, before suspension in a recorded volume of silicon oil (2000 centistokes). This was used as an equivalent measure of pollen concentration, counter to more familiar techniques of adding a known number of Lycopodium marker spores to a sample. For microscopy, all counts were aimed at $>150$ pollen per sample. Fern and fern ally spores were also recorded but were not included in the total palynomorph sum. The palynomorphs were identified using the reference collection of what is now the Department of Archaeology and Natural History, ANU (see www.palaeoworks.anu.edu.au). All microscopic charcoal 
fragments were counted using the point-count method of Clark (1982), calculated as $\mathrm{mm}^{2}$ $\mathrm{cm}^{-3}$. The percentages of selected palynomorphs (major taxa $>2 \%$ of total sum and a select range of indicator taxa), charcoal and total palynomorph concentration data were placed into stratigraphic diagrams using the program C2 Data Analysis version 1.5.2 (Juggins 2005).

\section{Results and interpretation}

The stratigraphy of the core is presented in Figures $3 \mathrm{a}, 3 \mathrm{~b}$ and $3 \mathrm{c}$, and divided into zones on the basis of the main vegetation signals and charcoal particle concentrations. The AMS radiocarbon dates from the bulk samples from the core are presented in Table 2, with the key features of each record and their palynological zones described in Table 3. Three phases of vegetation change are defined by the sequence from southeast Manus, demonstrating coastal edaphic changes in response to mid-Holocene sea-level fluctuations, followed by freshwater swamp forest development, and increasingly dryland forest dominance in the late Holocene. This later swamp forest-dryland phase is critical in that it allows some definition of land-use practices demonstrated by the presence of both horticultural (Colocasia) and tree-crop (e.g. Metroxylon and Aleurites) components.

Table 2. Radiocarbon ages from Lahakai core

\begin{tabular}{|l|l|l|l|}
\hline Sample name & Depth cm & Radiocarbon age BP & Calibrated age 2 $\sigma$ \\
\hline LKAI 1 & $210-220$ & $340 \pm 70$ & $151-500$ \\
\hline LKAI 2 & $480-495$ & $3654 \pm 185$ & $3463-4418$ \\
\hline LKAI 3 & $615-630$ & $5280 \pm 185$ & $5598-6394$ \\
\hline
\end{tabular}

All dates on bulk sediment. All ages calibrated using Calib v. 5.1.

Table 3. Palynological zones represented in the Lahakai Swamp sequence, Manus, and outlined on the basis of changes in dryland, wetland and human-impact signatures

\begin{tabular}{|l|l|l|l|}
\hline Zone & Dryland & Wetland & $\begin{array}{l}\text { Interpretation of human impact } \\
\text { and other disturbances }\end{array}$ \\
\hline $\begin{array}{l}5500-3000 \\
\text { cal. yr BP }\end{array}$ & $\begin{array}{l}\text { Most common taxa recorded } \\
\text { are Urticaceae/Moraceae, } \\
\text { Arecaceae (which increases } \\
\text { towards the top of the zone) } \\
\text { and Myrtaceae. }\end{array}$ & $\begin{array}{l}\text { High but declining values of } \\
\text { mangrove taxa Rhizophora and } \\
\text { Brugieral Ceriops, with minimal } \\
\text { representation of Pandanus and } \\
\text { Centrolepidaceae/Restionaceae. } \\
\text { Cyperaceae and cf Hypolytrum } \\
\text { increase towards the top of the } \\
\text { zone, as does Lumnitzera. }\end{array}$ & $\begin{array}{l}\text { Micro-charcoal particles high at } \\
\text { around 5000 cal. yr BP. Macro- } \\
\text { charcoal band at around } 4000 \text { cal. } \\
\text { yr BP particles. }\end{array}$ \\
\hline $\begin{array}{l}\text { 3000-500 } \\
\text { cal. yr BP }\end{array}$ & $\begin{array}{l}\text { Characterised by the } \\
\text { zecondary taxa Ulmaceae, } \\
\text { Poaceae and Castanopsisl } \\
\text { Lithocarpus. Macarangal } \\
\text { Mallotus (also secondary forest } \\
\text { taxa) and Urticaceae/Moraceae } \\
\text { increase towards the top of } \\
\text { the zone. }\end{array}$ & $\begin{array}{l}\text { Mangroves largely absent, } \\
\text { dominated by Cyperaceae. }\end{array}$ & $\begin{array}{l}\text { Fern spores increase in this zone, } \\
\text { with Lygodium showing a small } \\
\text { peak. Two bands of macro- } \\
\text { charcoal particles at around 1000 } \\
\text { cal. yr BP. }\end{array}$ \\
\hline $\begin{array}{l}\text { 500-present } \\
\text { Zone III }\end{array}$ & $\begin{array}{l}\text { Several taxa increase in this } \\
\text { zone, including Calophyllum, } \\
\text { Elacocarpus, Endospermum, } \\
\text { Myrtaceae, while the } \\
\text { secondary forest taxa common } \\
\text { in Zone II decrease. }\end{array}$ & $\begin{array}{l}\text { Cyperaceae is represented in } \\
\text { much lower proportions than in } \\
\text { the previous zone. Most wetland } \\
\text { taxa are poorly represented. }\end{array}$ & $\begin{array}{l}\text { Polypodium increase and } \\
\text { Dicranopteris appears consistently } \\
\text { for the first time. Micro-charcoal } \\
\text { particles high at around 500 cal. } \\
\text { yr BP. Two macro-charcoal bands } \\
\text { represented in this zone. Possible } \\
\text { and probable plant cultigens } \\
\text { including Colocasia and Aleurites } \\
\text { are first represented in this zone. }\end{array}$ \\
\hline
\end{tabular}




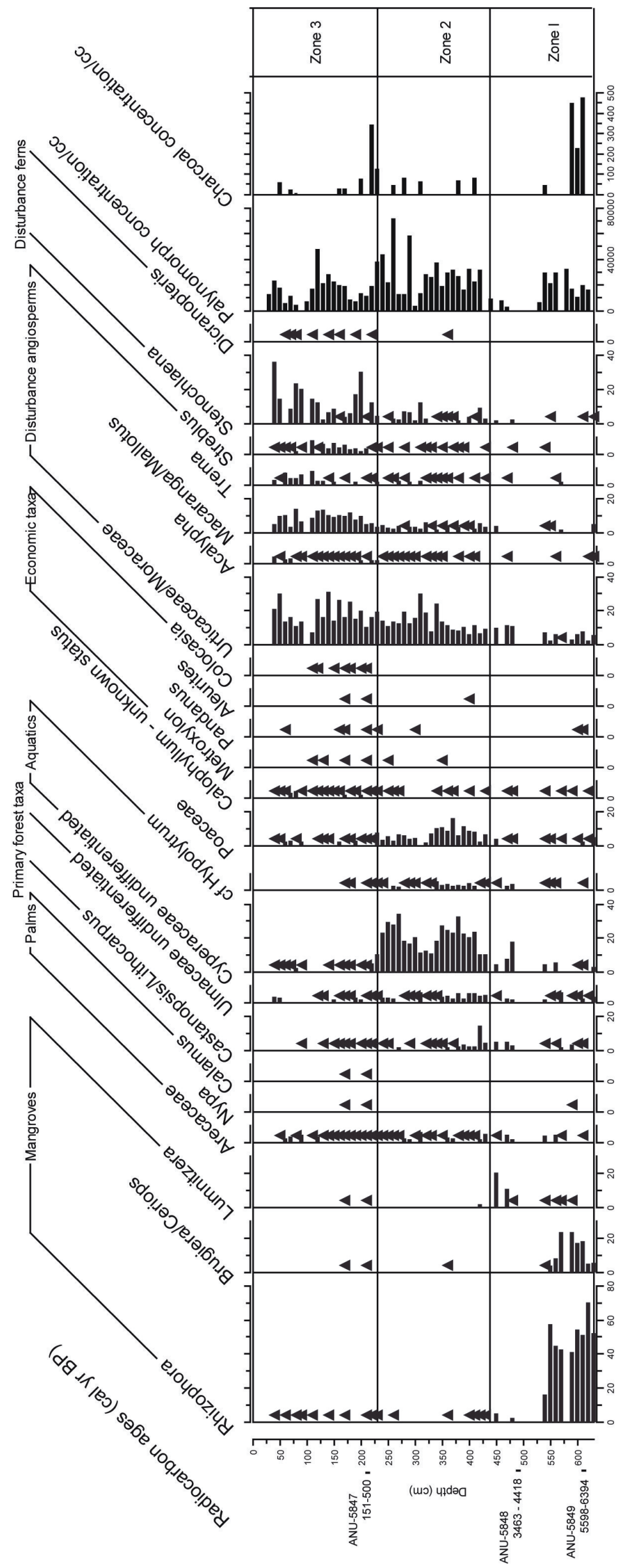

ॅ 흘 v

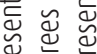

范范

지응

歨嵒

뜸.은

悹苍

产. 흠

突营:

突 $\stackrel{m}{E}$

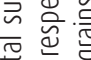

응

을

은

离

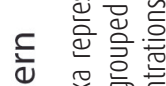

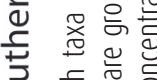




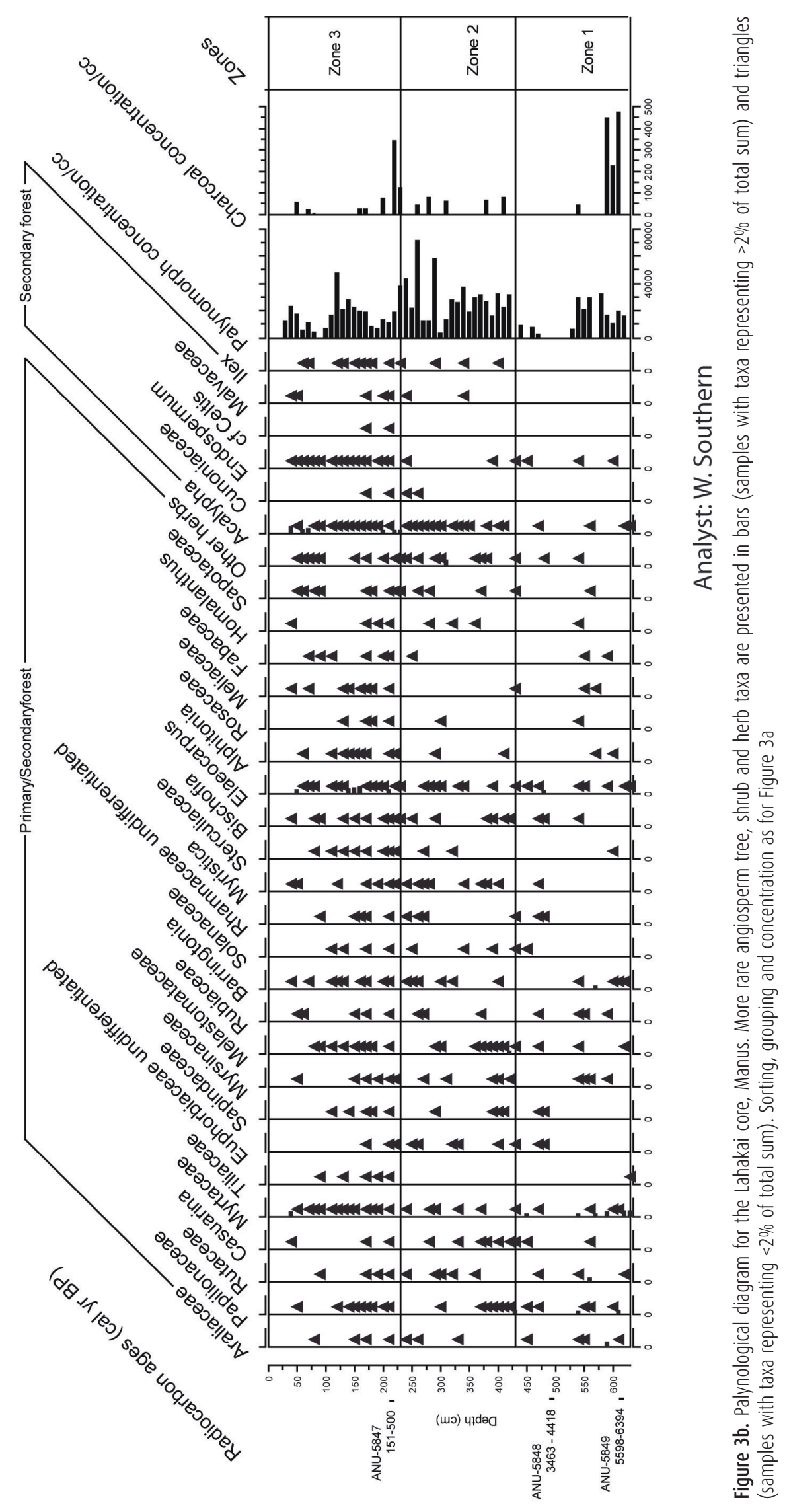




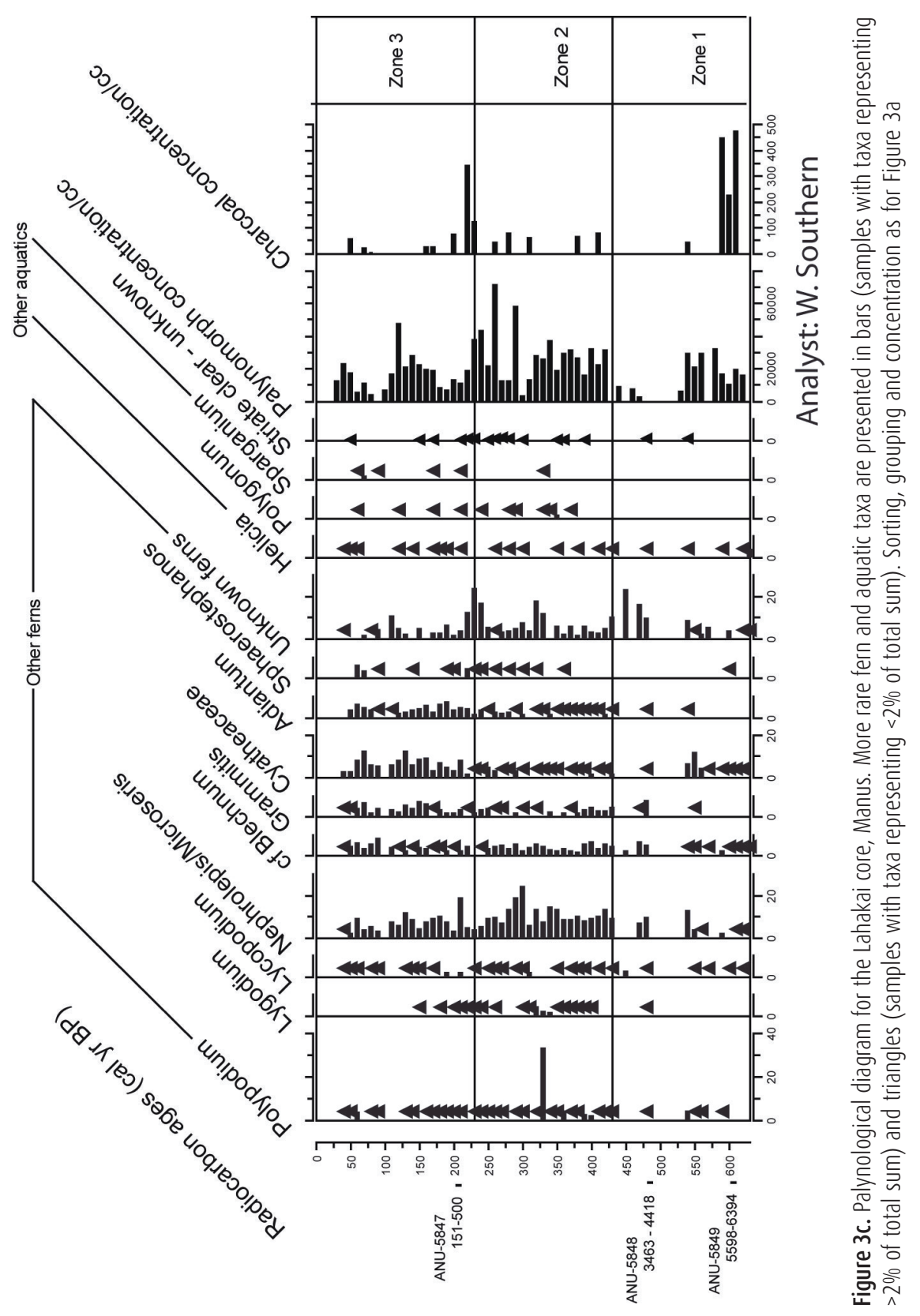




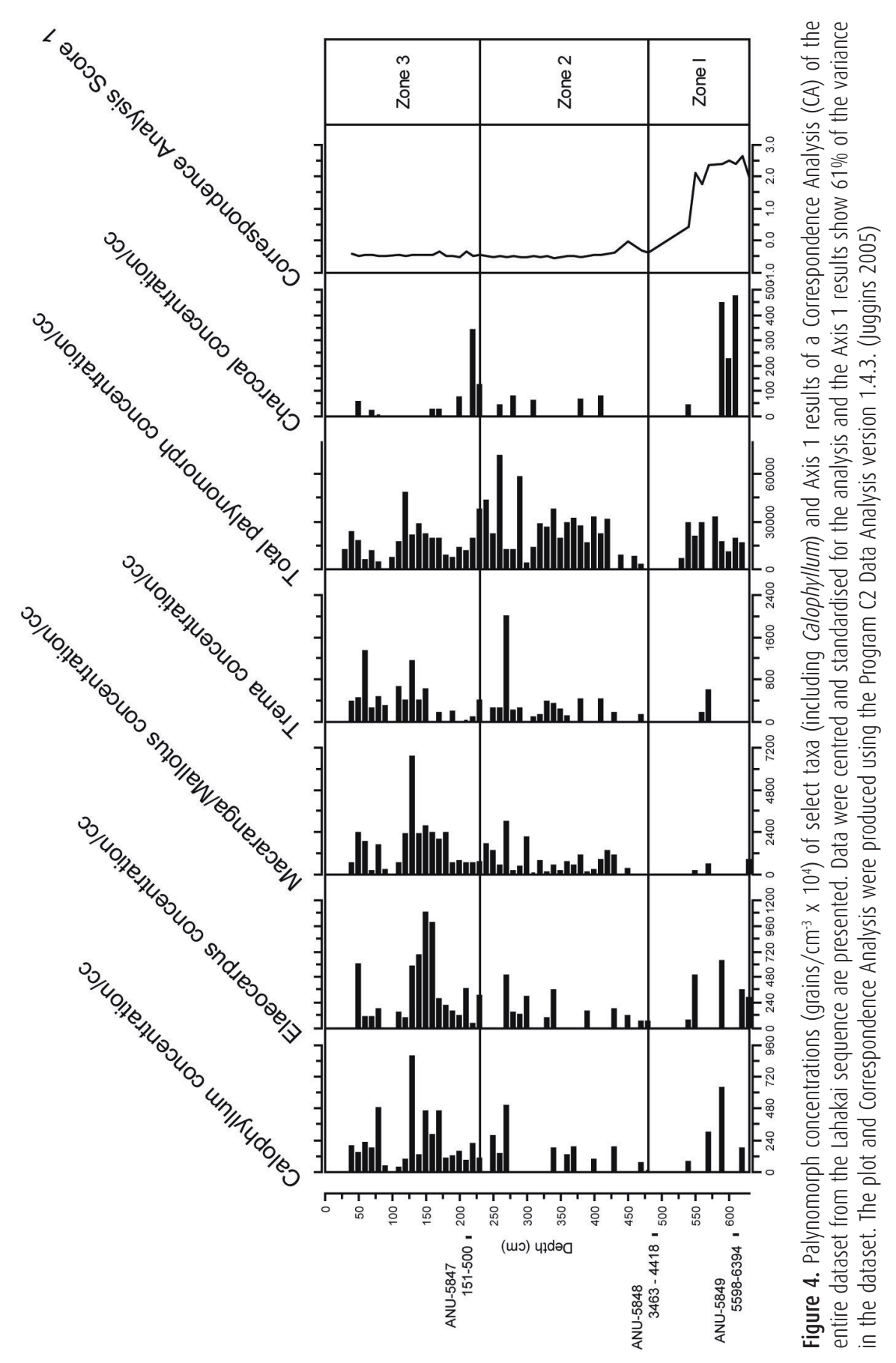


One of the most striking features of this record is the lack of Metroxylon sago pollen in the upper part of the sequence, despite the core site being intensively managed for sago production in 1987. One explanation for the lack of sago pollen in the upper sequence of this core is that most trunks of this hapaxanthic (monocarpic) tree have been harvested before flowering. An alternative, that pollen production in sago is low, is ruled out by modern pollen assemblages from surface swamp soils from under sago stands in other parts of Papua New Guinea (M. Prebble unpublished data). This discrepancy in pollen representation highlights the complexity of the interpretation of fossil pollen data. Pollen representation of Calophyllum, important for the southwest Manus sequence, presents another complex case.

\section{Calophyllum at Lahakai}

Although few data are available on the pollination ecology of Calophyllum, some taxa in the genus are known to be entomophilous (Stevens 2007) and thus probably do not produce high concentrations of pollen. It is very difficult to gauge from the percentage data presented from the Lahakai record the magnitude of the response of Calophyllum to any ecological changes, including human impact. To address the problem of pollen representation, in Figure 4 we show pollen concentration data for Elaeocarpus, a primary forest tree, Calophyllum, and the two key disturbance taxa, MacarangalMallotus and Trema. These data mitigate the proportional bias imposed by anemophilous (wind dispersed) and locally abundant taxa.

In Zones 1 and 2, Calophyllum is represented in similar concentrations to Elaeocarpus but is not consistently represented across all of the samples, suggesting that both these taxa were ephemeral in the Lahakai environment at this time. These data contrast with Macarangal Mallotus and Trema pollen, which are poorly represented in Zone 1, but are consistently represented across samples in Zone 2. All of these taxa are represented in all samples in Zone 3 and show similar changes in concentration across the zone. In Zone 2, the Calophyllum and Elaeocarpus concentrations are almost complementary, which suggests rapid changes in forest structure.

In order to assess whether these variations reflect changes exhibited across the entire record, correspondence analysis was performed on the percentage data of all pollen and spore taxa identified and all the samples analysed from the Lahakai core. Eigen values (Axis 1) generated for each sample are presented as proportions of the total variation in the dataset shown in Figure 4. These values account for $61 \%$ of the variation in the entire dataset, and are primarily controlled by the proportions of mangrove pollen in each sample. The greatest variation exhibited in this core occurs in Zone I. These data emphasise the point that variation in Zones 2 and 3 is minimal.

This raises the question of why Calophyllum behaves like a primary forest taxon in Zones 1 and 2 and a disturbance taxon in Zone 3.

\section{Calophyllum forest in Manus and the Pacific}

We have suggested that understanding the earlier settlement sequence of Manus requires understanding the dynamics of the forest. Since the growth of a forest dominated by Calophyllum spp. constitutes the most recent phase of the local sequence in southwest Manus, we consider what role this genus played in the southeast sequence represented at Lahakai. First, we review what is known of the ecology of Calophyllum in Manus and the wider region.

Information about the southwest Manus Calophyllum forest is limited but striking. Brief forestry and botanical surveys before logging began in 1988 highlighted its value for timber on the one hand, and ecological rarity on the other (Freyne and Bell 1982; Kerenga and Croft 1984/85; Stevens 1995:63). The area includes a very peculiar forest type, consisting of extensive plantation-like tracts in which large, even-sized Calophyllum euryphyllum Lauterb. (Clusiaceae) are almost the only tree, with abundant seedlings but virtually no saplings. 
This monotypic forest type also occurs on Rambutyo Island in Manus Province (Figure 1), on Mussau and on small islands off New Ireland, growing on a range of different soils and substrates (Kerenga and Croft 1984/85:46). There are no detailed descriptions or maps of the extent of the monotypic Calophyllum stands in southwest Manus or elsewhere.

C. euryphyllum has a scattered distribution on the Aru Islands, the islands of Geelvink Bay and the Vogelkop peninsula of Irian Jaya, the north coast of New Guinea from Jayapura to the Sepik, the Bismarck Archipelago (except New Ireland) and in the Central and Milne Bay provinces of Papua New Guinea (Stevens 1995). C. euryphyllum is the dominant species of the monotypic forest, but it is not the only Calophyllum species on Manus. C. soulattri and $C$. waliense, the latter an endemic Manus species, are also recorded. Although detailed distributions are lacking, it is likely these three species grow together (Stevens 1974:355). C. inophyllum, a widespread Malesian strand species, is also indigenous to Manus, but is primarily adapted to the coastal fringe, though it can grow on wetland substrates (Stevens 1974, 1980, 1995, 2007).

Apart from the monotypic stands of C. euryphyllum, Calophyllum spp. are common trees in the rainforest canopy throughout Manus (Kerenga and Croft 1984/85). In central and southcentral Manus, moderately rich mixed forest including Calophyllum spp. showed no distinct dominants (Kerenga and Croft 1984/85:44-46). In the survey of Manus forest resources that led to logging in western Manus, Freyne and Bell (1982:32-33) estimated that Calophyllum (species not identified, but probably mostly C. euryphyllum) comprised about $50 \%$ of the largest size class $(\mathrm{dbh}<70 \mathrm{~cm}$ ) of trees in two out of three sampled rainforest blocks, and $84 \%$ in the third, the western Manus block that includes monotypic stands.

In a subsequent preliminary study in the southwest Manus logging area, O'Collins and Lamothe (1989) identified 11 forest associations including canopy, subcanopy and regenerating vegetation in logged, unlogged and burnt forests. Three forest types were also identified from an old coconut (Cocos nucifera) plantation. Calophyllum (cf. C. euryphyllum) dominated all forest types with the exception of logged sub-canopy forest and the canopy and sub-canopy forests of an old coconut plantation, where this tree forms a minor component of the vegetation.

In eastern Manus, Calophyllum is absent from forest regrowth in lowland areas heavily disturbed by human interference (Kerenga and Croft 1984/85:45). In interior eastern Manus, Rooney (1982) reported that Calophyllum-dominated rainforest forms a late stage of succession after clearance for taro (Colocasia) cultivation. He suggested that the conversion of earlier woody fallow to forest dominated by 'Calophyllum and tropical hardwood species', which local inhabitants consider undesirable for taro gardens, resulted from management failure caused by labour shortage, following a modernisation movement in the 1940s that halved the local population (Rooney 1982:275). Though details of the species composition of this forest are unclear, Rooney's comment does not suggest monotypic Calophyllum stands.

Despite the scarcity of quantified descriptions, it seems that the frequency of Calophyllum spp. in Manus forest is variable, and that the monotypic stands of western Manus, Rambutyo and small islands off New Ireland represent a rare occurrence of hyper-dominance, the dynamics of which are unknown.

The survey of forest resources of Manus asserts that Calophyllum (species not stated) is a pioneer (Freyne and Bell 1982:29, 34). The basis for this statement seems to be the observation of seedlings in disturbed areas, but perhaps also the assumption that the even size of trees in the monotypic stands translates to even age. There is no comment about the absence of saplings in these stands noted by Kerenga and Croft (1984/85). Freyne and Bell's (1982:35) stand table showing regeneration of saplings, the only such data available for Manus, relates to more typical rainforest, in which large Calophyllum trees constitute about half the volume of usable timber, rather than the much higher figure for the western Manus block containing the 
monotypic stands. Freyne and Bell (1982:29) attribute this peculiar formation to catastrophic destruction, citing a Manus colleague's account of an oral tradition about a tidal wave and strong wind, thought to have occurred in the early 19th century (see also Johns 1986).

If the monotypic C. euryphyllum forest of southwest Manus was composed of a pioneer species in even-aged stands, the timing of forest initiation could be estimated, and suggest a terminal date for the shift from a pattern of inland villages most likely supported by taro gardening and tree crops to a smaller population living in exclusively coastal villages supported by sago and other tree crops.

This explanation for the southwest Manus monotypic forest lacks evidence. The argument from oral history fails on a number of grounds. There has been no comprehensive study of Manus oral history, available information being anecdotal at best. Attributing damage throughout the uplands of southwest Manus, or Rambutyo, to tsunamis lacks credibility, given the elevation of the terrain. Stories of catastrophes, including earthquakes, darkness and drought as well as high winds and tsunamis causing forest, garden and village destruction, are commonly recounted throughout Manus (J. Kennedy pers obs. 1977-1991). They are undoubtedly based on observation, but a widely repeated story does not account convincingly for peculiar effects of a localised catastrophe. In central Manus, where villagers tell a very elaborate account of how a tidal wave and wind long ago destroyed the local forest, leaving only one tree, a large Ficus, still standing, there are no dense Calophyllum stands (J. Kennedy pers obs. 1981). There is no reliable support from oral history for a local catastrophe in southwest Manus that might account for natural disturbance-mediated establishment of Calophyllum forest.

As to even age of the trees, the foresters' assumption that fairly uniform diameter translates to even age has not been borne out since logging began in southwest Manus. Many trees are too old to be any use (Anon. 2004). Age variation both within and between stands suggests more complex dynamics of establishment, as do other traits of the species.

Elsewhere on Manus, C. euryphyllum is a common component of rainforest. Its local value as timber, especially for canoe hulls, makes it likely that trees would once have been protected or conserved. Although there is little in the literature about its ecology, Rooney's (1982:275) comment about its role in late-stage fallows is suggestive. A recent forestry development program to propagate genetically improved seed for community tree-planting programs (Gunn 2007) shows that the seed has very high moisture content and is unlikely to retain viability for long. It is eaten by birds, bats and phalangers (Anon. n.d.).

Although C. euryphyllum is distributed from the Aru Islands and the Vogelkop, along the north coast of New Guinea to the Bismarck Archipelago, occurrences of monotypic stands are restricted to a few areas in Manus, Mussau and islands off New Ireland. Yet throughout the species' range, large-scale disturbance is common. This includes the eastern half of Manus, which lacks monotypic Calophyllum stands despite being closest to the volcanic eruptive centres of Lou Island and the St Andrew Strait that are the most potent source of disturbance in the region. In eastern Manus, fallow gardens support a familiar range of large-leaved, fastgrowing pioneer species, in which Calophyllum is not prominent, if present at all (Rooney 1982; Kerenga and Croft 1984/85). While the reported distribution of monotypic stands of C. euryphyllum might well reflect incomplete knowledge, this is unlikely in the case of eastern Manus, or the case of New Britain, an island that has been thoroughly explored for its timber potential, and also has a rich recent history of natural catastrophes and widespread gardening.

Although there is little direct evidence of the ecology of C. euryphyllum, there is information to suggest its likely characteristics. All except one of the Papuasian species of Calophyllum surveyed in Stevens' (1980) systematic treatment of the genus are shade-tolerant rainforest trees (the exception is the common coastal/strand species C. inophyllum), with no evidence of pioneer habit. In Whitmore's (1989) expanded classification along a gradient from pioneers to progressively more shade-tolerant species, the Solomons Calophyllum species (C. neo-ebudicum 
and $C$. peekelii) both fall towards the shade-bearing end. Seeds have no dormancy and are poorly dispersed. Seedlings germinate readily in light or shade, but with high early mortality. Survivors grow up in high forest or small gaps (see also Greig-Smith et al. 1967; Whitmore 1984:89; Burslem and Whitmore 1996).

C. euryphyllum probably behaves in a similar fashion, with regeneration dependent on a population of seedlings rather than a seed bank. Thus, distribution of the trees may reflect conditions promoting the persistence and onward growth of seedlings into saplings, rather than the dispersal and germination of seeds (Bazzaz and Pickett 1980:293, 303). The monotypic C. euryphyllum forest is clearly a special case, requiring explanation of how other species are excluded. The absence of saplings noted by Kerenga and Croft (1984/85) suggests that the formation of monotypic stands involves peculiar dynamics in which on-growth of seedlings is suppressed, and that these may persist. It has been shown that in Bornean forests, most shaded seedlings of canopy tree species are at least 10 years old, and some may be much older (Delissio et al. 2002).

Ecological studies have examined forests where stands of Calophyllum spp. dominate, further east in the Pacific. Calophyllum neo-ebudicum occurs throughout Vanuatu in moist forest, but is most abundant in the southern islands of Erromango and Aneityum (Wheatley 1992; Mueller-Dombois and Fosberg 1998). On Aneityum, the natural vegetation is dense mixed lowland forest with a canopy of C. neo-ebudicum and Agathis obtusa, but much of this forest has been extensively logged, leaving much of the island in secondary scrub (Hope pers comm.). C. neo-ebudicum is the most common canopy associate in Erromango.

Drake et al. (1996) documented four types of forest on the raised limestone island of 'Eua, Kingdom of Tonga, two dominated by $C$. neo-ebudicum. The key feature of this study is the recognition that regeneration of disturbed areas in these forest types is not dominated by $C$. neo-ebudicum, but Dendrocnide harveyi (Urticaceae), Bischofia javanica (Euphorbiaceae) and Rhus taitensis (Anacardiaceae) in the mixed forest, and Alphitonia zizyphoides (Rhamnaceae) and Elattostachys falcata (Sapindaceae) in the upland Calophyllum forest. This suggests that disturbance has not maintained C. neo-ebudicum dominance, but instead supports a more diverse mixed forest assemblage.

Whitmore's long-running study of the regeneration of forests on Kolombangara, in the Solomon Islands, monitored all age classes of 12 canopy species on a range of sites and under disturbance conditions which included cyclone damage and gardening clearance, as well as small natural gaps (Whitmore 1989; Burslem and Whitmore 1996, 1999). Burslem et al. (2000) discuss forest regeneration after cyclone damage, to evaluate the suggestion that community composition of tropical forests may be influenced strongly by rare but largescale disturbance events. They conclude that the relative abundance of common tree species on Kolombangara is only briefly disrupted by such events, and that a better explanation for spatial differences in the island's forest composition is provided by different histories of human disturbance. Bayliss-Smith et al. (2003) reach a similar conclusion for the Marovo lagoon area, and argue the value of interdisciplinary studies for understanding of rainforest dynamics.

As Whitmore (1989) showed for Kolombangara, the considerable spatial and temporal differences in population size and turnover of tree species following canopy disturbance make generalisations about forest dynamics unsafe. The functional and life-history characteristics of tree species vary independently across multiple parameters, which dichotomous typologies cannot reflect (Baker et al. 2003; Kraft et al. 2008; Zimmerman et al. 2008:111). Studies of relative species abundance and distribution in tropical forests, based on repeated censuses of large plots, have highlighted the difficulties of testing competing theories of the maintenance of the species diversity of tropical forests (Chave 2004, 2008; Carson and Schnitzer 2008). Notably, seedling-to-sapling stages of tropical forest dynamics have not yet been satisfactorily investigated (Zimmerman et al. 2008:108). 
The high diversity of tropical forests is the central focus of studies of their ecology and dynamics. Recent approaches have shifted from relatively simple deterministic models to more sophisticated theoretical models, which integrate ideas from island biogeography and population genetics and have greater analytical power, especially capability to handle large datasets at multiple scales. A central issue generating much debate is whether stochastic dispersal-dependent sampling effects and demographic processes are sufficient to account for community structure, and the extent to which species-level differences in ecological strategy contribute to this structure (e.g. Connell 1978; Denslow 1987; Hubbell 2001; Potts et al. 2002; Chave 2004; Svenning et al. 2004; Wills et al. 2006; Carson and Schnitzer 2008; Kraft et al. 2008; Stokstad 2009). Recognition that tropical forests often have a few common species and a large number of rare ones has become central to the development of these insights in forest community ecology. Dealing quantitatively with spatial patterning of the rare species has required new approaches to both data collection and analysis, especially to measures of biodiversity (Chave 2004, 2008).

\section{Monodominant tropical canopy species}

High diversity notwithstanding, at the other extreme of the range of relative species abundance, dominance of the canopy by single species, ranging from $50 \%$ to $100 \%$ of individuals, is common throughout the tropics and has drawn extended commentary. Connell and Lowman (1989) classified these forests into two types, on the basis of whether or not the monodominant species persists beyond one generation. Stands of short-lived, light-demanding species with well-dispersed seeds capable of long dormancy do not regenerate in situ. Persistent dominance of the canopy by one species, they suggest, could arise in two ways: by colonisation of large gaps and subsequent regeneration, or by gradual replacement of other species. They proposed ectomycorrhizal association as one possible mechanism for such replacement and listed species which show persistent dominance from the families Dipterocarpaceae, Fagaceae, Lauraceae and Leguminosae (subfamily Caesalpinioideae), from Malesia and the New World.

Subsequent research has shown that monodominant canopy species do not share a simple set of causative traits or mechanisms. They may form at early or late successional stages after clearance, and this does not predict whether they regenerate or not. Those that form persistent stands of long-lived trees may or may not depend upon ectomycorrhizae or poor soils. Examples have expanded to include more species of the families Leguminosae, Guttiferae, and notably New Guinea and New Caledonian Nothofagus species (Connell and Lowman 1989; Hart et al. 1989; Hart 1990; Read et al. 1995, 2000; Torti et al. 2001; Potts et al. 2002; McGuire 2007).

C. euryphyllum on Manus provides another example of monodominance in a family (Clusiaceae) not included in recent discussions. Forest in which C. euryphyllum constitutes about $50 \%$ of canopy trees appears to be quite widespread throughout Manus. Calophyllum species further east in the Pacific seem to follow a similar pattern. The restricted patches in which C. euryphyllum reaches much higher proportions, in the west of Manus, on Rambutjo and elsewhere, we have singled out above as monotypic, emphasising not only the species' dominance but also the distinctive lack of growth stages between seedlings and mature trees.

Research on tropical canopy monodominance establishes the multiplicity of possible causal mechanisms, rendering generalisation unsafe. We need more evidence to explain both the widespread pattern of Calophyllum spp. dominance on Pacific islands, and especially the hyperdominance of the monotypic C. euryphyllum stands. On present evidence, it is impossible to decide whether the Lahakai pollen data might represent the more widespread, c. $50 \%$ dominance of Calophyllum spp. on Manus, or the rarer patches of monotypic stands. 


\section{Conclusion}

The Calophyllum-rich forests of Manus are part of an island landscape that has supported a human population since the Pleistocene. We lack the detailed evidence necessary to show how people have impacted forest vegetation and vice versa. Nevertheless, Calophyllum spp are represented in both our local sequences, one based on a phase of human occupation on top of which has grown a distinctive monotypic forest, the other on palaeoecological signals from an area which archaeological evidence shows was well populated. In the most recent phase of both sequences, Calophyllum is somewhat anomalous, represented by a peculiar forest in the west, and a divergent pollen signal in the east.

Since we lack the observational data crucial for understanding the ecology of these trees and their community dynamics, we cannot make direct causal links between the former human settlement of the interior of southwest Manus and the succeeding monotypic forest, nor between the palynological record of Lahakai Swamp and the human activity represented by the nearby archaeological site. Nevertheless, the southwest Manus archaeological landscape makes it clear that the absence of human settlement in the recent forest of western Manus was not a permanent condition, and that the forest almost certainly post-dates agricultural disturbance. On the other hand, in eastern Manus, agricultural activities have continued to the present. This contrast in the history of human activity might be correlated with the distribution of monotypic Calophyllum forest. One possibility is that the monotypic stands formed after a pattern of moderate-scale, relatively frequent disturbance initiated by agriculture was interrupted by a gradual cessation of garden clearance, so that both frequency and scale of disturbance decreased. Tests of this hypothesis are offered by the unstudied archaeological potential and as yet undescribed ecological characteristics of other occurrences of monotypic C. euryphyllum forest, on Manus, Rambutyo and elsewhere. Further efforts to understand the phylo- and phytogeography of Calophyllum spp. in the southwest Pacific are warranted, including palaeoecological research focused on mapping the temporal and spatial distribution of Calophyllum from local sequences.

We conclude by noting that the benefits of interdisciplinary research include rephrasing and refocusing complex questions, such those posed by the ecological histories of islands, as much as answering them.

\section{Acknowledgements}

This paper draws on field work in Manus Province supported by the Manus Provincial Government and people of Mbunai village and Ndrahuke logging camp. Over its long and complex gestation, many people have helped with information and advice. They include Wal Ambrose, Tim Bayliss-Smith, Bill Clarke, Jim Croft, Brian Gunn, Ian Hughes, Bob Johns, Malcolm Levett and Peter Stevens. We thank them, and anonymous referees for constructive comments. 


\section{References}

Allen, J. 1991. Introduction. In J. Allen and C. Gosden (eds), Report of the Lapita Homeland Project. Occasional Papers in Prehistory 20, pp1-8. Canberra: Department of Prehistory, Research School of Pacific Studies, Australian National University.

Allen, J. 2000. From beach to beach: The development of maritime economies in prehistoric Melanesia. In S. O'Connor and P. Veth (eds), East of Wallace's Line: Studies of past and present maritime cultures of the Indo-Pacific region. Modern Quaternary Research in Southeast Asia 16, pp139-175. Rotterdam: Balkema.

Allen, J. 2003. Discovering the Pleistocene in Melanesia. In C. Sand (ed.), Pacific Archaeology: Assessments and prospects. Proceedings of the International conference for the 50th anniversary of the first Lapita excavation. Le Cahiers de l'Archéologie en Nouvelle Calédonie 15, pp33-42. Nouméa: Départemente Archéologie, Service des Musées et du Patrimoine de Nouvelle-Calédonie.

Allen, J. and C. Gosden (eds) 1991. Report of the Lapita Homeland Project. Occasional Papers in Prehistory 20. Canberra: Department of Prehistory, Research School of Pacific Studies, Australian National University.

Allen, J. and C. Gosden 1996. Spheres of interaction: Modelling the culture history of the Bismarck Archipelago. In J. Davidson, G. Irwin, B.F. Leach, A. Pawley and D. Brown (eds), Oceanic Culture History: Essays in honour of Roger Green. NZ Journal of Archaeology Special Publication, pp183-197. Dunedin: NZ Journal of Archaeology.

Ambrose, W. 1988. An early bronze artefact from Papua New Guinea. Antiquity 62:483-491. Ambrose, W. 1991. Lapita or not Lapita? The case of the Manus pots. In J. Allen and C. Gosden (eds), Report of the Lapita Homeland Project. Occasional Papers in Prehistory 20, pp103-112. Canberra: Department of Prehistory, Research School of Pacific Studies, Australian National University.

Ambrose, W. 2002a. From very old to new, obsidian artefacts in the Admiralty Islands. In C. Kaufmann, C. Kocher Schmid and S. Ohnemus (eds), Admiralty Islands: Art from the South Seas, pp67-72. Zürich: Museum Rietberg.

Ambrose, W. 2002b. Big pots on a small Lou Island. In S. Bedford, C. Sand and D. Burley (eds), Fifty years in the field. Essays in honour and celebration of Richard Shutler Jr's archaeological career, pp59-67. Auckland: New Zealand Archaeological Association.

Anonymous 2004. Review of current logging projects. Finalised individual project review report 2, Timber Permit 18-2 West Coast Manus. Papua New Guinea: Department of National Planning and Monitoring.

Anonymous n.d. Nursery techniques and seed handling of PNG's tree species. Waigani: PNG Forest Industries Association (Inc).

Baker, T.R., M.D. Swaine and D.F.R.P. Burslem 2003. Variation in tropical forest growth rates: Combined effects of functional group composition and resource availability. Perspectives in Plant Ecology, Evolution and Systematics 6:21-36.

Bazzaz, F.A. and S.T.A. Pickett 1980. Physiological ecology of tropical succession: A comparative review. Annual Review of Ecology and Systematics 11:287-310.

Bayliss-Smith, T., E. Hviding and T. Whitmore 2003. Rainforest composition and histories of human disturbance in Solomon Islands. Ambio 32:346-352.

Bedford, S. and G. Clark 2001. The rise and rise of the Incised and Applied Relief Tradition: A review and reassessment. In G. Clark, A. Anderson and S. Sorovi-Vunidilo (eds), The Archaeology of Lapita Dispersal in Oceania. Terra Australis 17, pp61-74. Canberra: Pandanus Books.

Burslem, F.R.P. and T.C. Whitmore 1996. Silvics and wood properties of the common timber tree species on Kolombangara. D.F.R.P. Oxford Forestry Institute Tropical Forestry Papers 34. Solomon Islands Forest Records 7. University of Oxford: Oxford Forestry Institute. 
Burslem, F.R.P. and T.C. Whitmore 1999. Species diversity, susceptibility to disturbance and tree population dynamics in tropical rain forest. D.F.R.P. Journal of Vegetation Science 10:767-776.

Burslem, F.R. P., T.C. Whitmore and G.C. Brown 2000. Short-term effects of cyclone impact and long-term recovery of tropical rain forest on Kolombangara, Solomon Islands. D.F.R.P. Journal of Ecology 2000 88:1063-1078.

Carson, W.P. and S.A. Schnitzer (eds) 2008. Tropical forest community ecology. Chichester, UK: Wiley-Blackwell.

Chappell, J. 2005. Geographic changes of coastal lowlands in the Papuan past. In A. Pawley, R. Attenborough, J. Golson and R. Hide (eds), Papuan Pasts: Cultural, linguistic and biological histories of Papuan-speaking peoples, pp525-539. Canberra: Pacific Linguistics, RSPAS, ANU.

Chave, J. 2004. Neutral theory and community ecology. Ecology Letters 7:241-253.

Chave, J. 2008. Spatial variation in tree species composition across tropical forests: Pattern and process. In W.P. Carson and S.A. Schnitzer (eds), Tropical forest community ecology. pp11-30. Chichester, UK: Wiley-Blackwell.

Clark, R.L. 1982. Point count estimation of charcoal in pollen preparations and thin sections of sediments. Pollen et Spores 24:523-535.

Connell, J.H. and M.D. Lowman 1989. Low-diversity tropical rain forests; Some possible mechanisms for their existence. American Naturalist 134: 88-119.

Delissio, L.J., R.B. Primack, P. Hall and H.S. Lee 2002. A decade of canopy-tree seedling survival and growth in two Bornean rain forests: Persistence and recovery from suppression. Journal of Tropical Ecology 18:645-658.

Denham, T.P., Haberle, S.G. and Lentfer, C. 2004. New evidence and revised interpretations of early agriculture in Highland New Guinea. Antiquity 78:839-857.

Denslow, J.S., 1987. Tropical rainforest gaps and tree species diversity. Annual Review of Ecology and Systematics 18:431-451.

Drake, D.R., Whistler, W.A., Motley, T.J. and Imada, C.T. 1996. Rain forest vegetation of 'Eua, Kingdom of Tonga. New Zealand Journal of Botany 34:65-77.

Ellison, J. 2005. Holocene palynology and sea-level change in two estuaries in southern Irian Jaya. Palaeogeography, Palaeoclimatology, Palaeoecology 220:291-309.

Faegri, K. and J. Iversen 1975. Textbook of pollen analysis. Copenhagen: Munksgaard.

Fairbairn, A. 2005. An archaeobotanical perspective on Holocene plant-use practices in lowland northern New Guinea. World Archaeology 37:487-502.

Flannery, T and J.P. White 1991. Animal translocation. National Geographic Research and Exploration 7:96-113.

Fredericksen, C., M. Spriggs and W. Ambrose 1993. Pamwak rock shelter: A Pleistocene site on Manus Island, Papua New Guinea. In M.A. Smith, M. Spriggs and B. Fankhauser (eds), Sahul in review: Pleistocene archaeology in Australia, New Guinea and Island Melanesia. Occasional Papers in Prehistory 24, pp144-152. Canberra: Department of Prehistory, Research School of Pacific Studies, Australian National University.

Freyne, D.F. and G.S. Bell 1982. Forest and land resources of Manus and Los Negros Islands. Research Bulletin 31. Papua New Guinea: Department of Primary Industry.

Garret-Jones, S.E. 1979. Evidence for changes in Holocene vegetation and lake sedimentation in the Markham Valley, Papua New Guinea. Unpublished PhD thesis, Australian National University, Canberra.

Ghai, Y and A.J. Regan 1992. The law, politics and administration of decentralisation in Papua New Guinea. Monograph 30. Papua New Guinea: National Research Institute.

Golson, J. 2005. Introduction to the chapters on archaeology and ethnology. In A. Pawley, R. Attenborough, J. Golson and R. Hide (eds), Papuan Pasts: Cultural, linguistic and biological histories of Papuan-speaking peoples, pp221-233. Canberra: Pacific Linguistics, RSPAS, ANU. 
Gosden, C. 1992. Production systems and the colonization of the western Pacific. World Archaeology 24:55-69.

Gosden, C. 1993. Understanding the settlement of Pacific Islands in the Pleistocene. In M. A. Smith, M. Spriggs, B. Fankhauser (eds), Sahul in review: Pleistocene archaeology in Australia, New Guinea and Island Melanesia. Occasional Papers in Prehistory 24, pp131136. Canberra: Department of Prehistory, Research School of Pacific Studies. Australian National University.

Gosden, C. 1995. Arboriculture and agriculture in coastal Papua New Guinea. In J. Allen and J. O'Connell (eds), Transitions: Pleistocene to Holocene in Australia and Papua New Guinea. Antiquity Special No. 265, pp807-817. Oxford: Oxford University Press.

Green, R.C. 2003. The Lapita horizon and traditions signature for one set of Oceanic migrations. In C. Sand (ed.), Pacific Archaeology: Assessments and prospects. Proceedings of the International conference for the 50th anniversary of the first Lapita excavation. Le Cahiers de l'Archéologie en Nouvelle Calédonie 15, pp95-105. Nouméa: Départemente Archéologie, Service des Musées et du Patrimoine de Nouvelle-Calédonie.

Greig-Smith, P., M.P. Austin and T.C. Whitmore 1967. The application of quantitative methods to vegetation survey. I. Association analysis and principal component ordination of rain forest. Journal of Ecology 55:483-503.

Gunn, B. 2007. Facilitating the availability and use of improved germplasm for forestry and agroforestry in Papua New Guinea. ACIAR Papua New Guinea and Solomon Islands Nius 2(2):1-4.

Haberle, S.G. 1995. Identification of cultivated Pandanus and Colocasia in pollen records and the implications for the study of early agriculture in New Guinea. Vegetation History and Archaeobotany 4:195-210.

Haberle, S.G. 1998. Late Quaternary vegetation change in the Tari Basin, Papua New Guinea. Palaeogeography, Palaeoclimatology, Palaeoecology 137:1-24.

Haberle, S.G. and B. David 2004. Climates of change: Human dimensions of Holocene environmental change in low latitudes of the PEPII transect. Quaternary International 118-119:165-179.

Haberle, S.G. 2007. Prehistoric human impact on rainforest biodiversity in highland New Guinea. Philosophical Transactions of the Royal Society B: Biological Sciences 362:219-228.

Hart, T.B. 1990. Monospecific dominance in tropical rain forests. Trends in Ecology and Evolution 5:6-11.

Hart, T.B., J.A. Hart and P.G. Murphy 1989. Monodominant and species-rich forests of the humid tropics: Causes for their co-occurrence. American Naturalist 133:613-633.

Heinsohn, T. 2003. Animal translocation: Long-term human influences on the vertebrate zoogeography of Australasia (natural dispersal versus ethnophoresy). Australian Zoologist 32:351-376.

Hide, R.L., B.J. Allen, R.M. Bourke, D. Fritsch, R. Grau, J.L. Helepet, P. Hobsbawn, S. Lyon, M. Poienou, S. Pondrilei, K. Pouru, G. Sem and B. Tewi 1996. Manus Province: Text summaries, maps, code lists and village identification. Agricultural systems of Papua New Guinea Working Paper 18. Canberra: Department of Human Geography, Research School of Pacific and Asian Studies, Australian National University.

Hope, G.S. 1996. History of Nothofagus in New Guinea and New Caledonia. In T.T. Veblen, R.S. Hill and J. Read (eds), The Ecology and biogeography of Nothofagus forests, pp257-270. New Haven, Connecticut: Yale University Press.

Hope, G.S. 2007. Palaeoecology and palaeoenvironments of Papua. In A.J. Marshall and B.M. Beehler (eds), The Ecology of Papua, pp255-266. Singapore: Periplus Editions.

Hope, G.S. 2009. Environmental change and fire in the Owen Stanley Ranges, Papua New Guinea. Quaternary Science Reviews 28:2261-2276. 
Hope, G.S. and S.G. Haberle 2005. The history of human landscapes of New Guinea. In A. Pawley, R. Attenborough, J. Golson and R. Hide (eds), Papuan Pasts: Cultural, linguistic and biological histories of Papuan-speaking peoples, pp541-554. Canberra: Pacific Linguistics, RSPAS, ANU.

Hope, G.S. and J. Tulip 1994. A long vegetation history from lowland Irian Jaya, Indonesia. Palaeogeography, Palaeoclimatology, Palaeoecology 109:385-398.

Hubbell, S.P. 2001. The unified neutral theory of biodiversity and biogeography. Princeton and Oxford: Princeton University Press.

Johns, R.H. 1986. The instability of the tropical ecosystem in New Guinea. Blumea 31:341-371.

Juggins, S., 2005. C2 Data Analysis Version 4.2. Newcastle: University of Newcastle.

Kennedy, J. 1981. Lapita colonisation of the Admiralty Islands? Science 213:757-759.

Kennedy, J. 1982. Archaeology in the Admiralty Islands: Some excursions. Indo-Pacific Prehistory Association Bulletin 3:22-35.

Kennedy, J. 1983. On the prehistory of Western Melanesia: The significance of new data from the Admiralties. Australian Archaeology 16:115-122.

Kennedy, J. 1991. Who should protect Papua New Guinea's archaeological heritage? in S.M. Eoe and P. Swadling (eds), Museums and cultural centres in the Pacific, pp148-151. Port Moresby: Papua New Guinea National Museum.

Kennedy, J. 1992. Two years of archaeological salvage in southwest Manus. Research in Melanesia 16:167-174.

Kennedy, J. 1997. The loneliness of an obsidian source in southwest Manus. Archaeology in Oceania 32:85-96.

Kennedy, J. 2002. Manus from the beginning: An archaeological overview. In C. Kaufmann, C. Kocher Schmid and S. Ohnemus (eds), Admiralty Islands: Art from the South Seas, pp17-28. Zürich: Museum Rietberg.

Kennedy, J. and W. Clarke 2004. Cultivated landscapes of the southwest Pacific. RMAP Working Paper 50. Canberra: Resource Management in Asia Pacific Program, Research School of Pacific and Asian Studies, Australian National University.

Kennedy, J., F. Wadra, U. Akon, R. Busasa, J. Papah and M. Piamnok 1991. Site survey of southwest Manus: A preliminary report. Archaeology in Oceania 26:114-118.

Kerenga, K. and J. Croft 1984/85. Notes on the vegetation at the collection sites of the Division of Botany expedition to Manus, 1981. Science in New Guinea 11:43-49.

Kershaw, A.P. and B.P.M. Hyland 1975. Pollen transfer and periodicity in a rainforest situation. Review of Paleobotany and Palynology 19:129-38.

Kirch, P.V. 2000. On the road of the winds. Berkeley and Los Angeles: University of California Press.

Kraft, N.J.B., R. Valencia, and D.D. Ackerly 2008. Functional traits and niche-based tree community assembly in an Amazonian forest. Science 322:580-882.

Lilley, I. 2006. Archaeology in Oceania: Themes and issues. In I. Lilley (ed.), Archaeology of Oceania: Australia and the Pacific Islands, pp1-28. Oxford, UK: Blackwell Publishing.

McEldowney, H. and C. Ballard 1991. The Mouk site: Manus as paradox or parable in reconstructions of the Lapita Cultural Complex. In J. Allen and C. Gosden (eds), Report of the Lapita Homeland Project. Occasional Papers in Prehistory 20, pp92-102. Canberra: Department of Prehistory, Research School of Pacific Studies, Australian National University.

McGuire, K.L. 2007. Common ectomycorrhizal networks may maintain monodominance in a tropical rain forest. Ecology 88:567-574.

Mueller-Dombois, D. and F.R. Fosberg 1998. Vegetation of the tropical Pacific islands. New York: Springer-Verlag. 
National Geographic 2009. http://www.nationalgeographic.com/wildworld/profiles/ terrestrial/aa/aa0101.html accessed 1 September 2009.

O'Collins, M. and L. Lamothe 1989. The assessment of the impact of forest operations on the environment and village communities. Unpublished report of field work undertaken on the west coast of Manus by students of the Forestry Department, Papua New Guinea University of Technology, Lae.

O'Connell, J.F. and J. Allen 2004. Dating the colonization of Sahul (Pleistocene AustraliaNew Guinea): A review of recent research. Journal of Archaeological Science 31:835-853.

O'Connor, S. and J. Chappell 2003. Colonisation and coastal subsistence in Australia and Papua New Guinea: Different timing, different modes? In C. Sand (ed.), Pacific Archaeology: Assessments and prospects. Proceedings of the International conference for the 50th anniversary of the first Lapita excavation. Le Cahiers de l'Archéologie en Nouvelle Calédonie 15, pp17-32. Nouméa: Départemente Archéologie, Service des Musées et du Patrimoine de NouvelleCalédonie.

Osborne, P.L., N.V.C. Polunin, and R.G. Totome 1996. Sediments as indicators of ecosystem function in four contrasting lakes in Papua New Guinea. In F. Schiemer and K. Boland (eds), Perspectives in tropical limnology, pp131-149. The Netherlands: SPB Academic Publishing.

Potts, M.D., P.S. Ashton, L.S. Kaufman and J.B. Plotkin 2002. Habitat patterns in tropical rain forests: A comparison of 105 plots in northwest Borneo. Ecology 83:2782-2797.

Prebble et al. In prep.

Read, J., P. Hallam and J.-F. Cherrier 1995. The anomaly of monodominant tropical rainforests: Some preliminary observations in the Nothofagus-dominated rainforests of New Caledonia. Journal of Tropical Ecology 11:359-389.

Read, J., T. Jaffré, E. Godrie, G.S. Hope and J.-M. Veillon 2000. Structural and floristic characteristics of some monodominant and adjacent mixed rainforests in New Caledonia. Journal of Biogeography 27:233-250.

Rooney, W.J. 1982. Changing food supply systems in eastern inland Manus. In R.M. Bourke and V. Kesavan (eds), Proceedings of the second Papua New Guinea food crops conference, part 2, pp273-278. Papua New Guinea: Department of Primary Industry.

Seacology 2008. <http://www.seacology.org/projects/individualprojects/PNG_manus2008. htm> accessed 1 September 2009.

Southern, W. 1987. The vegetation history of Lahakai Swamp, Manus Island, Papua New Guinea: A preliminary report. Unpublished ms.

Specht, J. 2005. Revisiting the Bismarcks: Some alternative views. In A. Pawley, R. Attenborough, J. Golson and R. Hide (eds), Papuan Pasts: Cultural, linguistic and biological histories of Papuan-speaking peoples, pp235-288. Canberra: Pacific Linguistics, RSPAS, ANU.

Spriggs, M.J.T. 1997. The Island Melanesians. Oxford: Blackwell.

Spriggs, M. 2003. Post-Lapita evolutions in Island Melanesia. In C. Sand (ed.), Pacific Archaeology: Assessments and prospects. Proceedings of the International conference for the 50th anniversary of the first Lapita excavation. Le Cahiers de l'Archéologie en Nouvelle Calédonie 15, pp213-220. Nouméa: Départemente Archéologie, Service des Musées et du Patrimoine de Nouvelle-Calédonie.

Stevens, P.F. 1974. A review of Calophyllum L. (Guttiferae) in Papuasia. Australian Journal of Botany 22:349-411.

Stevens, P.F. 1980. A revision of the Old World species of Calophyllum (Guttiferae). Journal of the Arnold Arboretum 61:117-699.

Stevens, P.F. 1995. Guttiferae. In B.J. Conn (ed.), Handbooks of the flora of Papua New Guinea, Volume 3, pp61-125. Carlton, Victoria: Melbourne University Press. 
Stevens, P.F. 2007. Clusiaceae-Guttiferae. In K. Kubitzki, C. Bayer and P. F. Stevens (eds), The families and genera of vascular plants. Volume 9. Flowering plants: Eudicots: Berberidopsidales, Buxales, Crossosomatales, Fabales, Geraniales, Gunnerales, Myrtales, Proteales, Saxifragales, Vitales, Zygophyllales, Clusiaceae Alliance, Passifloraceae Alliance, Dilleniaceae, Huaceae, Picramniaceae, Sabiaceae, pp48-66. Springer.

Stokstad, E. 2009. On the origin of ecological structure. Science 326:33-35.

Svenning, J.-C., D.A. Kinner, R.F. Stallard, B.M.J. Engelbrecht and S.J. Wright 2004. Ecological determinism in plant community structure across a tropical forest landscape. Ecology 85:2526-2538.

Swadling, P. and G.S. Hope 1992. Environmental change in New Guinea since human settlement. In J.R. Dodson (ed.), The naive lands: Prehistory and environmental change in the South West Pacific, pp13-42. Melbourne: Longman Cheshire.

Terrell, J.E. 2004. Introduction: 'Austronesia' and the great Austronesian migration. World Archaeology 36:586-590.

Terrell, J.E. and R.L. Welsch 1997. Lapita and the temporal geography of Lapita. Antiquity 71:548-572.

Torti, S.D., P.D. Coley and T.A. Kursar 2001. Causes and consequences of monodominance in tropical lowland forests. American Naturalist 157:141-153.

Wadra, F. 1991. Around Club Mud: A descriptive catalogue of obsidian artefacts collected from southwest Manus, 1989-1991. Unpublished thesis, Postgraduate Diploma in Arts. Department of Anthropology and Sociology, University of Papua New Guinea, Waigani.

Walker, D. and Y. Chen 1987. Palynological light on tropical rainforest dynamics. Quaternary Science Reviews 6:77-92.

Wheatley, J. 1992. A guide to the common trees of Vanuatu. Port Vila, Vanuatu: Department of Forestry.

Whitmore, T.C. 1974. Change with time and the role of cyclones in the tropical rain forest on Kolombangara, Solomon Islands. Commonwealth Forestry Institute Paper 46. Oxford: University of Oxford.

Whitmore, T.C. 1984. Tropical rain forests of the Far East. 2nd edition. Oxford: Clarendon.

Whitmore, T.C. 1989. Changes over twenty-one years in the Kolombangara rain forests. Journal of Ecology 77:469-483.

Willis, K.J., L. Gillson and T.M. Brncic 2004. How 'virgin' is virgin rainforest? Science 304:402-403.

Wills, C., K.E. Harms, R. Condit, D. King, J. Thompson, F. He, H.C. Muller-Landau, P. Ashton, E. Losos, L. Comita, S. Hubbell, J. LaFrankie, S. Bunyavejchewin, H.S. Dattaraja, S. Davies, S. Esufali, R. Foster, N. Gunatilleke, S. Gunatilleke, P. Hall, A. Itoh, R. John, S. Kiratiprayoon, S. Loo de Lao, M. Massa, C. Nath, M.N.S. Noor, A.R. Kassim, R. Sukumar, H.S. Suresh, I-F. Sun, S. Tan, T. Yamakura and J. Zimmerman 2006. Nonrandom processes maintain diversity in tropical forests. Science 311:527-531.

World Wildlife Fund 2001. http://www.worldwildlife.org/wildworld/profiles/terrestrial/aa/ aa0101_full.html

Yen, D.E. 1991. Domestication: The lessons from New Guinea. In A. Pawley (ed) Man and a half: Essays in Pacific anthropology and ethnobiology in honour of Ralph Bulmer. Memoir 48, pp558-569. Auckland: The Polynesian Society.

Yen, D.E. 1996. Melanesian arboriculture: Historical perspectives with emphasis on the genus Canarium. In M.L. Stevens, R.M. Bourke and B.R. Evans (eds), South Pacific indigenous nuts. ACIAR Proceedings 69, pp36-44. Canberra: Australian Centre for International Agricultural Research.

Zimmerman, J.K., J. Thompson and N. Brokaw 2008. Large tropical forest dynamics plots: Testing explanations for the maintenance of species diversity. In W.P. Carson and S.A. Schnitzer (eds), Tropical forest community ecology, pp98-117. Chichester, UK: Wiley-Blackwell. 